\title{
Universiteit
}

Leiden

The Netherlands

\section{Clefts in Durban Zulu}

Cheng, L.L.; Downing, L.J.; Hartmann, K.; Veenstra, T.

\section{Citation}

Cheng, L. L., \& Downing, L. J. (2013). Clefts in Durban Zulu. In K. Hartmann \& T. Veenstra (Eds.), Linguistik Aktuell/Linguistics Today (pp. 141-163). Amsterdam: John Benjamins. doi:10.1075/la.208.05che
Version:
Publisher's Version
License:
Licensed under Article 25fa Copyright Act/Law (Amendment Taverne)
Downloaded from: $\quad$ https://hdl.handle.net/1887/3245248

Note: To cite this publication please use the final published version (if applicable). 


\title{
Clefts in Durban Zulu*
}

\author{
Lisa L.-S. Cheng \& Laura J. Downing \\ Leiden University / Göteborg University
}

In this paper, we argue that clefts in Zulu have a bipartite structure: a copular sentence with an adjoined DP/clause. This structure accounts for the prosody of clefts. Each constituent is parsed into a separate Intonation Phrase by the independently motivated phrasing algorithm of Zulu. It also accounts for the syntactic properties of Zulu clefts. We further argue that the nature of agreement in Zulu copular sentences support a pronominal predicate analysis.

Keywords: Prosody of clefts; copular sentences; pronominal predicate

\section{Background}

Cleft sentences in Durban Zulu (such as the example in (1)) look on the surface rather similar to their English counterparts. As we can see from the translation in English, the cleft sentence in Zulu in (1) also involves an optional copula (see Section 2, below), a pivot, followed by a clause which looks on the surface like a relative clause.

(1) ng-ùm-fú:ndi ó-phéké in-ku:kh’izo:lo COP-1-student REL.1-cook 9-chicken 5.yesterday

'It is the student who cooked chicken yesterday.'

In this paper, we show that this similarity is only superficial. We provide both prosodic and syntactic evidence to show that (a) the cleft sentence involves a copular sentence with an adjoined phrase/clause; (b) the pivot and the clause following the pivot do not belong to the same clause; (c) the element following the pivot can be a

\footnotetext{
* We would like to thank, first of all, Meritta Xaba, our Zulu language informant, for her patience and thoughtfulness in helping us learn about her language. We also thank Leston Buell and Thilo Schadeberg for discussion of some aspects of the data and analysis. We are grateful to audience members at the Clefts Workshop and two anonymous reviewers for helpful comments.
} 
DP (with a relative clause in it), or an adverbial clause, depending on the nature of the pivot; and (d) the copular sentence in cleft sentences involves a pronominal predicate.

The paper is organized as follows. In Section 2, we provide the core set of data and generalizations that need to be accounted for. In Section 3, we present the basic prosodic phrasing algorithm for Zulu in other constructions, and show that the prosodic phrasing of clefts provides a first argument for their bi-clausal structure. In Section 4, we provide syntactic arguments supporting the bi-clausal structure, and further discuss clefts involving temporal/locative elements. In Section 5, we discuss the copular sentence in the clefts, arguing for the presence of a pronominal predicate. Further, we examine how the post-pivot phrase/clause is interpreted in relation to the pivot.

\section{Structure of clefts: Data and generalizations}

The first step towards understanding the structure of clefts is to notice that clefts contain a copular clause. In Zulu, the copula is expressed by a depressor low tone and an optional segmental prefix, either $n g-, y(i)$-, or $w(u)$. (See Buell 2009; Doke 1961, and Poulos \& Msimang 1998.) This can be seen in the identificational sentences in (2), where the syllable following the copular prefix is low-toned: ${ }^{1}$

$$
\begin{aligned}
& \text { a. (ú-Si:pho) (ng-üm-phe:ki). } \\
& \text { 1-Sipho COP-1-cook } \\
& \text { 'Sipho is the cook.' } \\
& \text { b. (ûm-phe:ki) (ng-ù-Sì:pho). } \\
& \text { 1-cook COP-1-Sipho } \\
& \text { 'The cook is Sipho.' }
\end{aligned}
$$

As can be seen by comparing (3a) with (3b), the cleft pivot also begins with a copula: the lexical high tone of úm- in úm-fúndísi 'teacher' (as in (3a), when this word heads a relative clause) is replaced by the copular low tone when the same word is a pivot in a cleft (as in $(3 c))$ :

1. In the glosses, numbers indicate nominal agreement classes; ReL is 'relative subject marker'; OM is 'object marker' and TAM is 'tense aspect marker'. Note that high tones are marked with an acute accent, and low tones are typically not marked in the examples. We have particularly indicated copular low tones in examples like (2) and (3) for clarity. Parentheses indicate the prosodic phrasing; see Section 3, below, for more discussion. Square brackets indicate syntactic boundaries, mainly relative clause boundaries. 
(3) a. Subject relative clause

(úm-fúndísi [ó-thól-ê: in-dánda:tho)]

1-teacher REL1-find-TAM 9-ring

(ú-zo-thóla úm-klóme:lo).

1-FUT-get 3-reward

'The teacher who found the ring will get a reward.'

Clefted subjects - question-answer pair

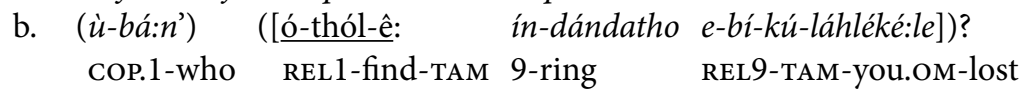

'Who is it that found the ring that got lost from you?'

c. (ùm-fúndí:si) ([ó-thól-ê: in-dándatho e-bí-ngi-láhléké:le]). COP.1-teacher REL1-find-TAM 9-ring REL9-TAM-I.oM-lost

'(It) is the teacher who found the ring that got lost from me.'

Another important difference between the subject relative in (3a) and the clefted subjects in $(3 b, c)$ is that each half of the cleft construction - pivot and relative clause - is always parsed into its own prosodic phrase. In contrast, relative heads in Zulu are generally phrased together with the rest of the relative clause, as shown in (3a), and the first phrase break falls at the right edge of the relative clause. The prosodic phrase boundaries can be easily identified in the data by the position of lengthened penult vowels. Vowel length is not contrastive, and long vowels are only found in the penult syllables of some words. Work since Doke (1961) analyzes penult length as a correlate of stress, and since Khumalo (1987) it is accepted that penult lengthening is a phrase level (not lexical) process.

This difference in prosodic phrasing is striking, as there is no segmental difference distinguishing the clauses marked as relative in (3). All contain a participial verb, with relative subject morphology. (See e.g. Doke 1961 for more detailed discussion of this morphology.) In all cases in (3), the relative verb is marked for (subject) agreement with what appears to be its head.

The independent prosodic phrasing of each half of the cleft is mirrored in the syntactic independence of the two halves. As shown in (4), the two halves of the cleft can appear in either order. However, restrictive relative clauses occur in a strict order, following their heads. (See also Section 4.2, below.)

(4) a.1 [In answer to, 'Who is carrying the basket?]
(ù-Nhlâ:nhla) (ó-thwél ú-bhasikí:di).
COP.1-Nhlanhla REL.1-carry 1-basket
'It is Nhlanhla who is carrying the basket.'

OR

a.2 (Ó-thwél' ú-bhasikí:di) (ù-Nhlâ:nhla).

REL.1-carry 1-basket COP.1-Nhlanhla

'The one who is carrying the basket is Nhlanhla.' 


\section{b.1 (ù-Sì:phó) (ó-phéka:-yo). \\ COP.1-Sipho REL.1-cook-REL \\ 'It is Sipho who cooks/is cooking.'}

OR
b.2 (ó-phéka:-yo) (ng-ù-Sî:pho).
REL.1-cook-REL COP-1-Sipho
'The one who cooks/is cooking is Sipho.'

Note that restrictive relative clauses and the relative clause half of a cleft in Zulu are morpho-syntactically indistinguishable from a headless relative, as shown in $(5 \mathrm{a}-\mathrm{c})$. We conclude from this, together with the data in (4), that the relative clause following these clefts is a headless relative (DP).

a. Headed relative clause

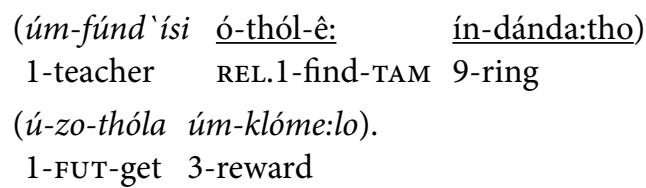

'The teacher who found the ring will get a reward.'

b. Headless relative

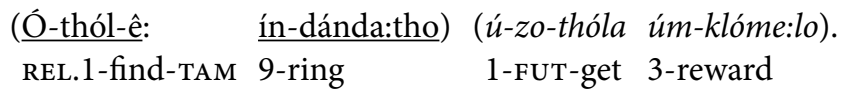

'The one who found the ring, s/he will get a reward.'

c. Cleft

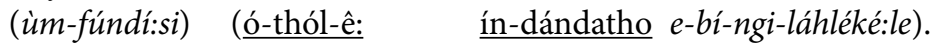 COP.1-teacher REL.1-find-TAM 9-ring REL.9-TAM-me.om-lost '(It) is the teacher who found the ring that got lost from me.'

A headless relative can be analyzed as a relative clause containing a null head; in other words, it is a DP. As we shall see shortly, headless relative clauses are not the only kind of complex DP which can occur as a dependent clause in a cleft construction. ${ }^{2}$

In all the examples of clefts so far, the pivot of the cleft corresponds to the subject of the dependent clause. Indeed, clefts are obligatory in Durban Zulu, as in many other Bantu languages, when questioning the subject and when answering

2. Despite their DP status, copulas cannot be attached to headless relatives. This is probably due to a morphological requirement on the copulas, that they attach to an overt nominal element. However, this topic requires further research. 
questions on the subject. ${ }^{3}$ Non-subject clefts commonly indicate contrastive or identificational focus. Examples of non-subject argument clefts are given below. Notice in these examples that the relative clause contains a resumptive object prefix in the verb or absolute pronoun (non-italicized) agreeing with the pivot:
a.1 (ng-àbá-ntwa:na) (éngi-zo-khúlúma na:-bo). COP.2-child REL.I-FUT-talk with-2
OR - reversed
a.2 (éngi-zo-khúlúma na:bo) (ng-àbá-ntwa:na). REL.I-FUT-talk with-2 cop-2-child
'It's the children who I will talk with.'
b.1 Q. (Yî̀-n’) (ó-nga-yí-ník-áng-a mu:-ntu)? COP.9-what REL.you-NEG-9.OM-give-NEG-FV 1-anyone 'What is it that you didn't give to anyone?'
b.2 A. (in-cwâ:d') (éngi-nga-yí-ník-áng-a mu:-ntu). COP.9-book REL.I-NEG-9.OM-GIVE-NEG-FV 1-anyone 'It's a book that I didn't give to anyone.'

c. [Context: Did they send the bicycle to Thandi?]
A. (châ:). (ù-Sî:ph') (ábá-m-thúmélél i-bhayiséki:li), no COP.1-Sipho REL.2-1.OM-sent to 5-bicycle
(hhá:y' ú-Tha:ndi).
not 1-Thandi

'No. It's Sipho they sent the bicycle to, not Thandi.'

In Zulu, not only arguments can occur as the pivot of clefts, but also adverbials. In fact, any wh-question word or morpheme can be clefted for emphasis. These examples share with the clefts we have seen so far the following properties: the cleft contains a copular sentence, each half of the cleft construction is parsed into its own prosodic phrase, and the two halves can be reversed.

However, the examples below also reveal differences. When complex whphrases or non-nominals are clefted, the dependent clause is not always a headless relative clause. Instead we find the following other possibilities:

- a headed relative clause with clefted 'which' question (7);

- an adverbial lapho...khona clause with clefted temporal or locative adjuncts, including 'when' and 'where' (8);

- a bare participial clause with the clefted question word, 'why' (9).

3. See Downing (2010), Maxwell (1981), van der Wal (2009), Walusimbi (1996) and Zerbian (2006) for discussion of other Bantu languages where clefts are normally required to focus the subject. 
The headed relatives in (7), contain a noun phrase, which agrees with the pivot of the cleft. The headed relative clause contains the typical relative subject prefix, resumptive object marker (for object relatives) or full pronoun, which agree with the pivot of the cleft.

(7) Clefted 'which', plus headed relative

a.1 (yì-mû:-phi) (úm-fúndisi ó-sí-bingeléla:-yo)?

COP-1-which 1-preacher REL.1-us.OM-welcome-REL

'Which preacher is welcoming us?'

[lit. 'It is which one, the preacher who is welcoming us?']

OR - reversed

a.2 (úm-fúndisi ó-sí-bingeléla:-yo) (ì-mû:-phi)?

1-preacher REL.1-us.om-welcome-REL COP-1-which

'Which preacher is welcoming us?'

[lit. 'The preacher who is welcoming us is which one?']

b.1 (in-cwád' ó-nga-yí-ník-á:nga mu:-nt') (i-yî:-phi)?

9-book REL.you-NEG-9.OM-give-NEG 1-anyone COP-9.which

OR - reversed

b.2 (ì-yî:-ph') (ín-cwád'ó-nga-yí-ník-ánga mu:-ntu)?

'Which book didn't you give to anyone?'

c.1 (ì-yî:-phi) (ín-dlu ó-béké kú-yóna izím-pháhla za:mi)?

COP-9-which 9-room REL.you-put LOC-9 10-thing 10.my

$\mathrm{OR}$ - reversed

c.2 (ín-dlu ó-béké kú-yóna ízim-pháhla za:m) (ì-yî:phi)?

'Which room did you place my things in?'

However, the clauses which accompany clefted adjuncts or clefted 'why' do not contain any agreeing morphology, as shown in (8) and (9), below:

(8) Clefted temporal or locative, plus lapho...khona clause

a. [Context: Did they put your things in my room?]

(ku-s-e-kámélwéní lí-ká-Si:phó) (lapho bé-béké

COP-LINKER-LOC-5.room.LOC 5-of.1-Sipho Adv PT2-put

kho:na) (izi-mphá:hla) (hhá:yí kwé-lá:kho).

Adv 10-thing not Loc-5.your

'It is in Sipho's room where they put the things, not in yours.'

4. The attentive reader will note in these examples that the words for 'preacher' and 'teacher' in Zulu are segmentally identical, but tonally distinct. 
b. (yì-kusá:sa) (lapho ngí-zo-ya kho:n') (é-Thékwí:ni), cop-tomorrow Adv PT.I-FUT-go Adv LOC-Durban.LOC

(hhá:yí namhlâ:nje). not today

'It is tomorrow that I will leave for Durban, not today.

c. (be-kú-y-izo:lo) (laph'úm-fúnd' e-phékélé kho:n') BE-17-COP-5.yesterday Adv 1-student PT.1-cook.for Adv

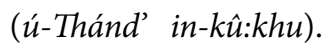

1-Thandi 9-chicken

'It was yesterday that the student cooked chicken for Thandi.'

d. (yì-kwâ:mi) (laph'izo:lo) (ú-Síph'é-phékélé kho:n')

COP-LOC.my Adv 5.yesterday 1-Sipho PT.1-cook.for Adv

(ú-Thánd' in-kû:khu).

1-Thandi 9-chicken

OR- reversed

e. (laph'izo:l') (ú-Síph'é-phékélé kho:na) (ú-Thánd' in-kû:khu) (yì-kwâ:mi).

'It is at my house that Sipho cooked chicken for Thandi yesterday.'

Moreover, the participial clause accompanying a clefted 'why' question does not contain any subordinate marking, other than the participial morphology on the verb (indicated as PT in the glosses):

(9) Clefted question word, 'why', plus bare participial clause

(y-î:nga:n’) (ú-Síph' é-phuzî:l') úkú-fí:ka)?

COP-why 1-Sipho PT.1-be late INFINITIVE-arrive

'Why is it that Sipho arrived late?'

[lit. 'It is why, Sipho is late to arrive?']

These morpho-syntactic distinctions between the participial clauses and the relative clauses which occur in cleft constructions are highlighted in the examples below, which show that nouns with adverbial meaning can head either a restrictive relative clause or an adverbial lapho...khona clause in non-cleft constructions. In cleft constructions, when the pivot of the cleft is adverbial, the dependent clause can only be a lapho...khona clause. Note that we find different subject prefixes participial vs. relative - in the two dependent clauses, and that only the relative clause contains a resumptive pronoun (non-italicized) agreeing with the head:

(10) Minimal pairs, relative vs. adverbial clausal modifiers
a.1 (índa:wo) (laph' ú-Síph' é:-khandelé: khon' i-mo:t’) (í-shí:le). 9.place Adv 1-Sipho PT.1-fix Adv 9-car 9-burn $\mathrm{OR}$ - relative clause (ku-yona resumptive for indawo) 

a.2 (índaw' ú-Síph' â:-khandelá kú-yón’ í-mo:t’) (î-shí:le.)
9.place 1-Sipho REL.1-fix LOC-9 9-car 9-burn
'The place where Sipho fixed the car burned down.'
b.1 (ú-su:kú) (lapho ú-Sípho é-phékélé é-mzi-ni wá:kho)
11-day Adv 1-Sipho PT.1-cook LOC-3.home-LOC 3.your
(kho:na) (lú-qalé ka:mbi).
Adv 11-begin badly

$\mathrm{OR}$ - relative clause:
b.2 (ú-súk' ú-Síph' á-phekelé nga-l’ é-mzi-ni wá:kho)
11-day 1-Sipho REL.1-cook Prep-11 Loc-3.home-LOC 3.your
(lú-qalé ka:mbi).
11-begin badly

'The day when Sipho cooked at your house began badly'

Let us sum up the important generalizations about Zulu clefts which our analysis needs to account for. Clefts have a bipartite structure: a copular sentence and a dependent clause. The prosodic phrasing provides one clue to the independence of each half of the cleft construction, as the pivot of the cleft forms an independent prosodic phrase from the dependent clause. Another clue to their independence is the fact that they can occur in either order. Both nominals and non-nominals can occur in the pivot of the cleft, and the type of dependent clause found in the second half of the clefted structure is conditioned by the nature of the pivot. Clefted nominals are accompanied by headless relative clauses. Clefted 'which' questions are accompanied by headed relatives. Clefted adverbials are accompanied by participial clauses, and in the case of clefted 'why', the participial clause is otherwise bare of subordinating morphology.

We develop our syntactic analysis of the structure of clefts in Section 4. First, we provide, as necessary background, the analysis of prosodic phrasing in Zulu.

\section{Prosodic phrasing in Durban Zulu and the phrasing of clefts}

We begin our analysis of the structure of clefts, by taking a closer look at the implications of the prosodic phrasing for their syntactic structure. Cheng and Downing's $(2007,2009,2012)$ work on prosodic phrasing in a range of Zulu constructions demonstrates that the right edge of phases, $v \mathrm{P}$ and $\mathrm{CP}$, systematically correlates with a prosodic phrase break, while the left edges of these constituents only variably condition phrase breaks. ${ }^{5}$ Evidence for a prosodic phrase break at the

5. Following Chomsky (2001), we take CP to be a phase. See An (2007), Fox and Pesetsky (2005) and Ishihara (2007) for discussions of whether $v \mathrm{P}$ in a particular language is a phase or not. 
right edge of CP comes from the fact that we find a break following, but not preceding, restrictive relative clauses and other embedded clause types - see (11c, d, e). Simple subjects are only variably followed by a prosodic phrase break, as we can see in $(11 a, b, c)$.
a. ([ ${ }_{\mathrm{CP}} u ́ m$-fúndísi ú-fúndel-ê: ábá-zal' ín-cwa:di.]) 1-teacher 1-read to-тAм 2-parent 9-letter 'The teacher read to the parents a letter.'
b. (ú-Si:pho) (ú-yí-phékéla ba:ni) (ín-ku:khu)?
1-Sipho 1-9.om-cook.for who 9-chicken
'Who is Sipho cooking the chicken for?'
c. ([ ${ }_{\mathrm{CP}}$ ú-Síph' ú-fún' [ ${ }_{\mathrm{CP}}$ úkúth' ú-Thándi á-théng' i-bhayiséki:li.]]) 1-Sipho 1-want that 1-Thandi 1-buy 5-bicycle 'Sipho wants Thandi to buy a bicycle.'
d. ([ ${ }_{\mathrm{CP}}\left[{ }_{\mathrm{CP}}\right.$ Ín-dod'é-gqoke ísí-gqo:ko]) (í-bon-é izi-vaká:shi. $\left.]\right)$ 9-man REL.9-wear 7-hat 9-see-TAM 8-visitor 'The man who is wearing a hat saw the visitors.'
e. $\quad\left({ }_{\mathrm{CP}}\right.$ si-phul $\quad{ }_{\mathrm{CP}}$ ím-baz' é-théngw-é we-break 9-axe REL.9-be.bought-TAM today
'We broke the axe that has been bought today'.

Evidence for a prosodic phrase break at the right edge of $v \mathrm{P}$ comes from the phrasing of adjuncts. Arguments must precede locative and temporal adjuncts, in a broad focus context or VP focus context like that illustrated in (12). Locative and temporal adjuncts are also separated from the preceding arguments by a prosodic phrase boundary. Both these facts are consistent with adjoining locative and temporal adjuncts above the $v \mathrm{P}$.

(12) Context: Q: What did Sipho do?

A: a. (ú-Síph' ú-phék' in-ku:khu) (kwám'izo:lo).

1-Sipho 1-cook 9-chicken Loc.my 5.yesterday

'Sipho cooked chicken at my place yesterday'

b. (bá-ník' ú-Síph' i-bhayiséki:li) (namhlâ:nje).

2-gave 1-Sipho 5-bicycle today

'They gave Sipho a bicycle today.'

We account for these prosodic phrasing generalizations in Edge-based alignment theory. (See, e.g. Selkirk 1986, 1995, 2000; Truckenbrodt 1995, 1999, 2005.) The basic parsing algorithm in the Edge-based theory requires one edge of a major syntactic constituent to coincide with an edge of a prosodic constituent, Phonological

As Cheng and Downing (2009) argue, when subjects are followed by a prosodic phrase break, they are plausibly in Topic position. 
Phrase or Intonation Phrase. Phonological Phrases coincide with lexical XPs, while Intonation Phrases coincide with functional XPs. We follow work like An (2007), Ishihara (2007), Kahnemuyipour (2009) and Kratzer and Selkirk (2007) in proposing that prosodic domains can also be conditioned by phases: $v \mathrm{P}$ and CP. The constraints below, relevant for Zulu prosodic phrasing in a broad focus context, together optimize a strict match between the right edge of syntactic phases and the right edge of Intonation Phrases: ${ }^{6}$

(13) ALIGNR[PHASE, INTPH]: Align the right edge of every phase $(\mathrm{vP} / \mathrm{CP})$ with the right edge of an Intonation Phrase (IntPh).

(14) ALIGNR[INTPH, PHASE]: Align the right edge of every Intonation Phrase $(\mathrm{IntPh})$ with the right edge of a phase $(\mathrm{vP} / \mathrm{CP})$.

The analysis of broad focus phrasing is exemplified in the tableaux below. Parentheses continue to indicate prosodic phrase boundaries:

(15) Broad focus phrasing

(a) Two arguments

\begin{tabular}{|c|l|c|}
\hline & ALIGNR-PHASE & ALIGNR-INTPH \\
\hline ii. S V IO) DO $\left.\left.]_{\mathrm{VP}}\right]_{\mathrm{VP}}\right]_{\mathrm{CP}}$ ) & & \\
\hline
\end{tabular}

(b) Argument plus Adjunct

\begin{tabular}{|c|c:c|}
\hline & ALIGNR-PHASE & ALIGNR-INTPH \\
\hline ii. S V DO DO $\left.\left.]_{\mathrm{VP}}\right]_{\mathrm{VP}}\right]_{\mathrm{VP}}$ Adj $\left.\left.\mathrm{Adj}\right]_{\mathrm{IP}}\right]_{\mathrm{CP}}$ ) & & \\
\hline
\end{tabular}

In tableau (15a), with two arguments following the verb in a broad focus context, it is optimal to parse both arguments with the verb in a single Intonation Phrase. Phrasing the arguments separately from each other, as in (15a.ii), violates the alignment constraint in (14): the phrase breaks are not both at a phase edge. In contrast, in sentences with an argument and an adjunct following the verb in a broad focus context, it is optimal for a phrase break to fall between the argument and the adjunct, as in candidate (15b.i). Phrasing the argument and adjunct together, as in candidate (15b.ii), violates the constraint in (13): the right edge of the $v \mathrm{P}$ phase is not aligned with an Intonation Phrase break.

6. See Cheng and Downing $(2009,2012)$ for detailed motivation of these two phase-phrase alignment constraints in Zulu. 
The prosodic phrasing we find in broad focus contexts has clear implications for the syntactic analysis of clefts in Zulu. Since the clefted head is phrased separately from the dependent clause, whatever order the two occur in, each half of the cleft structure must be separated by a phase edge - $v \mathrm{P}$ or $\mathrm{CP}-$ from the other half. The next sections develop syntactic arguments supporting this proposal.

\section{Zulu clefts: Analysis}

In this section, we first briefly discuss why a monoclausal structure for clefts cannot account for the data in Zulu. In 4.2, we present arguments supporting a bi-clausal analysis for both nominal and temporal/locative clefted elements.

\subsection{Arguments against a monoclausal embedding structure}

The prosodic phrasing of clefts provides our first argument against a monoclausal structure for cleft sentences. A typical monoclausal analysis can have the structures schematized in $(16 \mathrm{a}, \mathrm{b})$, with the pivot of the cleft either in SpecCP or in SpecFocusP. (See É. Kiss 1998 for such an analysis of clefts in English and some other languages):

$$
\begin{array}{ll}
\text { a. } & {\left[\mathrm{IP} \text { - copula }\left[{ }_{\mathrm{CP}} \text { clefted-phrase }\left[{ }_{\mathrm{C}} \text { clausal predicate/RC }\right]\right]\right]} \\
\text { b. } & {\left[\mathrm{IP} \text { - copula }\left[{ }_{\mathrm{FP}} \text { clefted-phrase }\left[{ }_{\mathrm{CP}} \text { clausal predicate/RC }\right]\right]\right]}
\end{array}
$$

Regardless of whether we are dealing with SpecCP or SpecFocusP, the prosodic phrasing of clefted sentences cannot be accounted for by this kind of analysis, nor can it account for the difference in prosodic phrasing between relative clauses and cleft sentences. As we have argued above, in $\mathrm{Zulu}$, the right edge of a phase ( $\mathrm{vP}$ or $\mathrm{CP}$ ) is privileged in its alignment with the right edge of an Intonation Phrase. Given the structures in (16a, b), no prosodic break between the pivot and the clause following the pivot is expected because a right phase edge does not follow the clefted phrase. This means that clefts and restrictive relative clauses are expected to have the same prosodic phrasing, contrary to fact.

Given a structure such as (16a, b), the assumption is that what is clefted is an $\mathrm{XP}$ constituent, and what follows the pivot is either part of a CP or a whole CP. However, as we have shown above in (7a) (repeated here as (17)), when the cleft involves a which-phrase, what follows which is a noun phrase with a relative clause in it, not a clausal predicate:

(yì-mû:-phi) (úm-fúndisi ó-sí-bingeléla:-yo)? COP-1-which 1-preacher REL.1-us.OM-welcome-REL

'Which preacher is welcoming us?' 
In other words, given (17), it appears that the pivot can be simply an element such as muphi 'which', and what follows is a noun phrase with a relative clause in it. In other words, neither the prosodic break following the pivot nor the type of phrase following the pivot can be accounted for, if the pivot is in SpecCP or SpecFocusP rather than at a right CP edge. (See also Wedgwood 2007.)

Note that a Kaynian relative clause structure does not rescue the monoclausal structure because the prosodic phrasing of (17) is still unexpected: the left edge of a CP does not align with an edge of the Intonation Phrase. An additional problem for a structure such as (16b), which involves a FocusP above the CP, is that Zulu does not have a high FocusP. (See Buell (2009), Cheng and Downing (2009, 2012), and Hyman and Polinsky (2010) for detailed discussion.)

\subsection{A bi-clausal structure}

We propose that both nominal and non-nominal clefts involve a copular sentence (an identificational sentence), with an appositive phrase/clause adjoined to the sentence. Consider first argument clefts, such as the sentence with a subject cleft in (3b), repeated here as (18a). We suggest that it has the structure in (18b).
a. (ùm-fúndí:si) [(óo-thól-ê:
in-dándatho e-bí-ngi-láhléké:le)]. COP.1-teacher REL.1-find-TAM 9-ring REL.9-TAM-me.oM-lost '(It) is the teacher who found the ring that got lost from me.'
b. $\quad{ }_{\mathrm{CP}}\left[_{\mathrm{IP}}\right.$ ùm-fúndí:si $\left.]\right]\left[_{\mathrm{DP}} ø\right.$ [ ${ }_{\mathrm{CP}}$ ó-thól-ê: ín-dándatho e-bí-ngi-láhléké:le]]

In this structure, the pivot of the cleft is in a copular sentence, and the headless DP with the relative clause is adjoined to the copular sentence. This structure is similar to the structure of French cleft sentences proposed by Clech-Darbon et al. (1999). (See also Koch 2008 for a similar analysis of clefts in Thompson River Salish.)

Given this structure, the pivot of the cleft will be at the right edge of a CP. As the right edge of $\mathrm{CP}$ consistently conditions a prosodic phrase break in Zulu, this structure correctly accounts for the prosodic parse of clefts.

\subsection{Headed relatives}

The structure in (18b) not only accommodates headless relatives like the one given in (18a), but also cases involving headed relatives, like those discussed above with which-phrases. In (19) we repeat (7c), above, to illustrate this:

$$
\begin{array}{rrll}
\left.\left({ }_{\mathrm{CP}}\left[{ }_{\mathrm{IP}} i-y \hat{i}:-p h i\right]\right]\right) & \left(\left[_ { \mathrm { DP } } \left[_{\mathrm{CP}} i n-d l u\right.\right.\right. & \text { ó-béké } & \text { kú-yóna } \\
\text { COP-9-which } & \text { 9-room } & \text { REL.you-put } & \text { LOC-9 }
\end{array}
$$

izím-pháhla za:mi]])?

10-thing 10.my

'Which room is it that you put my things in?'

[lit. 'It is which [one], the room that you put my things in?'] 
We suggest that yiphi in (19) constitutes, in fact, a full noun phrase, with a null head in it (i.e. it has the reading which one). The noun class 9 prefix further supports the proposal that $y i$-phi is a noun phrase.

It should be noted that aside from the clefted which-phrases such as the one in (19), we find other kinds of clefts with a headed relative following a copular sentence. In particular, in certain situations (as we see below), a pronoun associated with the head of the relative clause can appear in the copular sentence. To understand the structure of these clefts, one must first consider copular sentences involving predicate nominals, as in (20a) and its negative counterpart in (20b):

$$
\begin{aligned}
& \text { a. ng-ùmû:-ntu lo:ná. } \\
& \text { cop-1-person 1.that } \\
& \text { 'That's a person.' }
\end{aligned}
$$

b. a-kú-ye:n' úmú:-ntu lo:ná. NEG.COP-17-1PRO 1-person 1.that (adapted from Buell 2008) 'That's not a person.'

In the negative form in (20b), not only do we see the class 17 subject marker in the copular sentence, there is also a pronoun, yena, which accords with the noun class of the following noun, umuntu. These pronouns (non-italicized) also show up in negative clefts, as shown in (21):
a. (a-kú-bo:na)
(ábá-fána kuphê:la) (áb-enzá lo:kho). NEG.COP-17-2PRO 2-boy only REL.2-do 17.that 'It's not just the boys who did that'.
$\begin{array}{llll}\text { b. } \quad(a-k u ́ \text {-ye:n’ } & \left(u_{\text {-tíshá }}\right. & \text { éngi-m-ázi:-yo }) & \text { (lona } \\ \text { NEG.COP-17-1PRO } & 1 \text {-teacher } & \text { REL.I-1.OM-know-REL } & \text { 1.PRO }\end{array}$ ó-bónwe u-Sî:pho). REL.1-be seen by.1-Sipho 'It's not the teacher that I know [the one] that was seen by Sipho.'

Aside from negation contexts, we also see the pronoun showing up when there is an additional emphasis on the copular sentence (similar to verum focus), as in (22):
a. (ngù-yê:n') (ú-Síph' ow-énza lo:kho). COP-1PRO 1-Sipho REL.1-do 17.that
'It IS Sipho who does that.'
b. (kwá-kú-yi-bô:na) (ábá-fán' áb-enzá lo:kho). 17.PAST-17-COP-2PRO 2-boy REL.2-do 17.that 'It WAS the boys who did that.'

In all these cases, there is a prosodic phrase break right after the pronoun. This follows from our analysis - the copular sentence here ends with the pronoun, and it is thus at the right edge of a prosodic phrasal boundary, and the DP following the 
copular sentence is a headed relative clause. ${ }^{7}$ The literal translation of (22b), for instance, is: 'It was them, the boys who did that'. These sentences show that a headed relative clause following the pivot of the cleft is actually not an option limited to which-phrases, but can be found in other constructions involving clefted pronouns.

\subsection{Non-nominal clefts}

We have shown in examples in (10) that non-argument clefts are followed by a non-relative participial clause. With temporal and locative elements, the participial clause is headed by lapho, which may indicate time or place, and the adverbial khona appears in the clause. In the case of a clefted why-question, the clause that follows it is also a participial clause, though it is not headed by an overt marker. Below, we first provide further examples to show that these participial clauses are not relative clauses. Note in the examples below that it is ungrammatical to use the relative subject prefix $a$-, rather than the participial subject prefix $e$-. The occurrence of a resumptive element (non-italicized) is also ungrammatical in these sentences but required in a relative clause:

Temporal/locative elements $-{ }^{*}$ sentences have relative morphology
a. (yì-kû:phi) (laph'ú-Síph' é-yí-thénge: kho:n') imí-fi:no) COP-where Adv 1-Sipho PT.1-4.OM-buy Adv 4-vegetables
b. *yì-kû:phi ú-Síph’ a-yi-thengá ku-yo:na imí-fi:no? COP-where 1-Sipho REL.1-4.OM-buy 17-PRO 4-vegetables 'Where did Sipho buy the vegetables?'
a. (yì-kwâ:mi) (laph'ú-Síph'izo:l’) (é-phékélé khon' COP-LOC.my Adv 1-Sipho 5.yesterday PT.1-cook.for Adv in-kúkhú ká-Tha:ndi).
9-chicken of.1-Thandi

b. *yì-kwâ:mi izo:lo ú-Síph' á-yí-phékelé ku-yo:na COP- LOC.my 5.yesterday 1-Sipho REL.1-9.oM-cook.for 17-pro ú-Tha:nd' in-kû:khu.

1-Thandi 9-chicken

'It is at my place that Sipho yesterday cooked chicken for Thandi.'

a. (yízo:lo $\quad$ (laph'um-fúnd' e-phékélé kho:n’)
Cop.5.yesterday Adv 1 -student PT.1-cook.for Adv
(ú-Ja:bu) $\quad$ (ín-ku:khu).
1-Jabu 9-chicken

7. We will not discuss here why the pronoun particularly shows up in negative or emphasis contexts. In the case of negation, we speculate that a $\mathrm{X}^{0}$ element (such as a pronominal element) can be used to support a negative head. 

b. *yízo:lo úm-fúnd' a-phékélé ngayo
COP.5.yesterday 1-student REL.1-cook.for prep.5PRO
úJab' in-kû:khu.
1-Jabu 9-chicken

'It is yesterday that the student cooked chicken for Jabu.'
a. (y-î:nga:n') (ú-Síph' é-phuzî̀l') (úkú-fí:ka)?
COP-why 1-Sipho PT.1-be.late INFINITIVE-arrive
b. ${ }^{*}$-ingani u-Sipho a-phuzile uku-fika? COP-why 1-Sipho REL.1-be.late INFINITIVE-arrive 'Why did Sipho arrive LATE?'

It should be noted that lapho clauses also occur in non-cleft contexts, as shown in (27), cited from Doke (1961), who unfortunately does not mark tone or phrase penult lengthening:
a. Lapho usu-qed-ile,
ma-wu-buye.
when yOu.PRT-finish-PERF HORT-you-return.sUBJUNCTIVE
'When you have finished, come back.'
b. Yi-beke in-cwadi lapho kade i-khona.
9.om-put.subjunctive 9-book where before cop-there
'Put the book where it was before.'

These examples illustrate that the lapho clauses are adverbial clauses.

We suggest that non-nominal clefts share with nominal clefts a structural property, namely, a copular sentence is involved. Instead of having a DP adjoined to the copular sentence as in the nominal clefts, however, we propose that an adverbial clause is adjoined to the copular sentence when it also contains an adverbial. ${ }^{8}$ This is illustrated with the structure of (25a), given in (28):

(28) $\left[_{\mathrm{CP}}\left[{ }_{\mathrm{IP}} \text { yízo:lo] }\right]_{\mathrm{CP}}\right.$ laph' úmfúnd’ e-phékélé kho:n’ úJa:b' ínku:khu]

In the next sections, we motivate this structure in more detail. First we show the dependent clause does not result from extraposition. Then we develop a proposal arguing that the Zulu cleft structure involves a pronominal predicate (cf. Moro (1997) and Adger and Ramchand (2003)).

8. In lapho...khona clauses one fairly consistently finds a prosodic phrase break following khona. This suggests, as we showed in Section 3, that khona is at the right edge of $v$ P. However, an object following khona is not resumed with object marking on the verb, as we would expect if it were external to $v$ P. These constructions obviously require more study in order to better understand these seemingly contradictory properties. Such an analysis is, though, outside the scope of this paper. What is crucial to the analysis developed here is that a lapho...khona clause is an adverbial, and occurs when the clefted pivot is also adverbial. 


\section{Motivating the structure}

\subsection{The post-pivot phrase/clause is not extraposed}

We begin by developing our argument that the post-pivot clause is not extraposed. Given the structure in (18b), one might consider the post-pivot clause on a par with a right-dislocated relative clause (under the assumption that it is not really a DP, but a CP). In other words, it might have the derivation suggested by Percus (1997) for English clefts. This is shown in (29). For the cleft sentence in (29), the base sentence starts out as a copular sentence with a subject containing a definite determiner and a null head (with a relative clause (CP) following the null head).

(29) a. It is John that Mary saw.

b. $\left[_{I P}\left[{ }_{D P} \text { the } 0\left[{ }_{C P} \text { OP }{ }_{i} \text { that Mary saw } t_{i}\right]\right]_{j}\left[{ }_{V P} t_{j}\right.\right.$ is John $\left.]\right]$

c. Extraposition

$\left[{ }_{I P}\left[\left[_{D P} \text { the } 0 t_{k}\right]_{j}\left[{ }_{V P} t_{j}\right.\right.\right.$ is John $\left.]\right]\left[\left[_{C P} O P_{i} \text { that Mary saw } t_{i}\right]_{k}\right]$

The relative clause is then extraposed, yielding the surface structure of a cleft (with the definite determiner and the null head subsequently spelled out as $i t$ ). The structure in (29c) appears similar to the structure that we have in (18b).

However, we argue that no right-dislocation is involved in Zulu clefts. First, there is no comparable right-dislocation possibility for relative clauses in nonclefted contexts in Zulu. The data in (30b) and (31b) show very clearly that relative clauses cannot be right dislocated:

$$
\begin{aligned}
& \text { a. [ [ }{ }_{\mathrm{DP}}\left(A ́ b a ́-n t w a ́ n '{ }_{\mathrm{CP}}\right. \text { ábá-jah' im-bû:zi)]] (ba-yá-hle:ka). } \\
& \text { 2-child REL.2-chase 9-goat 2-DJ-laugh }
\end{aligned}
$$

$$
\begin{aligned}
& \begin{array}{rrr}
{ }_{\mathrm{DP}}\left(\dot{u}_{\text {-thísha }}\right) & {\left[\mathrm{CP}_{\mathrm{CP}}\right. \text { ó-si-fundél' }} & \text { in-cwa:di) }]] \\
\text { 1-teacher } & \text { REL.1-us.om-read.to } & \text { 9-letter }
\end{array} \\
& \text { (ú-yá-si-thukuthéli:sa). } \\
& \text { 1-DJ-us.om-make.angry } \\
& \text { 'The teacher who is reading us a letter makes us angry'. } \\
& \text { b. *uthisha uyasithukuthelisa }{ }_{\mathrm{CP}} \text { ó-si-fundél' ín-cwa:di] }
\end{aligned}
$$

If normally relative clauses cannot be right dislocated, it is very difficult to motivate a right-dislocation analysis just in the case of the clefts. Further, as we have already pointed out for the cases in which we have a headed relative (i.e. involving a which-phrase), it cannot be the case that it is the relative clause (CP) alone that is right dislocated. 


\subsection{The copular sentence}

The next step in motivating the structure we argue for (i.e. (18b)) requires understanding the relation between the adjoined DP (in the case of a nominal DP pivot) or the adjoined adverbial clause (in the case of a non-nominal pivot), on the one hand, and the pivot on the other. To do this, we must take a closer look at the structure of the copular sentence. As we briefly mentioned above, in the case of nominal predication, the copula has three main segmental forms, $n g(a)-, y(i)$-, and $w(u)$. In $(32 \mathrm{a}-\mathrm{c})$, we see that the subject agreement marker (non-italicized in these data) normally precedes the copula:
a. Mina ngi-ng-úm-ngane wá:kho.
I.PRO I-COP-1-friend 1.your
'I am your friend.'
b. uSipho u-ng-u-thisha.
1.Sipho 1-COP-1-teacher
'Sipho is a teacher.'
c. izi-nkomo zi-yi-ngcosana.
10-cattle 10-COP-10.few
'The cattle are few.

(Buell 2008)

(adapted from Doke 1961)

The subject marker on the copula agrees with the subject of the copular sentence, just as the subject marker of a verbal sequence in a typical sentence reflects the noun class of the subject. However, the subject marker in (32b) is optional. This is the case if the subject is a third person (e.g. belongs to class 1), and the verbal form is in the principal (i.e. non-participial) mood. Compare, though, (32b) with (33) which illustrates the copular verbal form in a participial clause:

$$
\begin{array}{lll}
\text { uma } & u \text {-Sipho e-ng-u-thisha, ... } \\
\text { if } & \text { 1-Sipho PT1-Cop-1-teacher }
\end{array}
$$

'If Sipho is a teacher, ...'

Here, the copular sentence is in an if-clause, which requires that the verb be in the participial form, and the subject marker cannot be omitted.

Consider now subject agreement in clefts. None of the cleft sentences up to now show any subject marker in the pivot of the cleft. This makes the clefts look like they might contain a third person subject with a verbal form in the principal mood, just like (32b). The obvious way to test for the subject of the cleft is to put it in an if-clause, where the copula will be in the participial form and require subject marking (non-italicized). From comparing (34a) with (34b), we see that when the copula is in a participial clause, the subject marker is class 17, and not class 1 (third person human), as the ungrammatical (34c) shows. 
a. (ng)-ù-Sî:pho ó-phék' úku:-dl' izol' ébúsú:ku. cop-1-Sipho rel.1-cook 15-food 5.yesterday night 'It is Sipho who cooked dinner last night.'

b. úmá kú-ng-ù-Sî:pho ó-phék' úku:-dl' izol’ if 17-cop-1-Sipho rel.1-cook 15-food 5.yesterday

ébúsú:ku ngeké kú-dlè:ké.

night be.unable 15-be.eaten

'If it is Sipho who cooked dinner last night, it wouldn't be eatable.'

c. *uma e-ng-ù-Sì:pho ó-phék' úku:-dl' izol’ if 1-COP-1-Sipho REL1-cook 15-food 5.yesterday

ébúsú:ku ngéké kú-dle:ké.

night be.unable 15-be.eaten

The class 17 subject agreement marker can also be found in sentences comparable to the expletive construction in English, as shown in (35):

$$
\begin{array}{ll}
\text { ku-fik-e } & \text { izingane } \\
\text { 17-arrive-PERF.CJ } & \text { 10.children }
\end{array}
$$

(adapted from Buell 2008)

'There arrived some children.'

Buell $(2006,2008)$ has argued that in cases such as (35), the logical subject izingane 'children' stays internal to the verb phrase (thus explaining the conjoint form of the verb). ${ }^{9} \mathrm{Ku}$ appears as a default subject marker.

Turning back to the copular clause in cleft sentences, the class 17 subject marking we find also illustrates default agreement. Note that class 17 agreement prefix $k u$ - (non-italicized) not only appears with the participial mood, it also appears when the verb is in the past tense, as shown in (36a) or under negation, as shown in $(36 b, c)$ :

$$
\begin{aligned}
& \text { a. bé-kú-yî:ni) ú-Síphó á-bé-yí-phe:ka) } \\
& \text { BE-17-COP:what.9 1-Sipho REL.1-be.past-9.oM-cook } \\
& \text { é-mzi-ni } \\
& \text { wá:kho)? }
\end{aligned}
$$

LOC-3.home-LOC 3.your

'What was it that Sipho cooked at your house (this morning)?'

9. Zulu verbal forms distinguish between a conjoint (CJ) form and a disjoint (DJ) form. (See work like Buell 2005; Doke 1961; Poulous \& Msimang 1998, and van der Spuy 1993 for detailed discussion.) Simplifying a bit, the conjoint form is used when there is something following the verb in the verb phrase. In (35), the verb is conjoint, indicating that aside from the verb, something else, in this case the logical subject, is also in the verb phrase. 

b. a-kú-mi:n') ów-enza lo:kho).
NEG.COP-17-me.PRO REL.1-do 17.that
'It wasn't me who did that.'
c. a-kú-ye:na) ú-Sípho ó-phékê: úku:-dl')
NEG.COP-17-1PRO 1-Sipho REL.1-cook 15-food
izol' ébúsú:ku).
5.yesterday night
'It is not Sipho who cooked dinner last night.'

We conclude from these data that we have class 17 agreement in the copular sentence in the case of clefts.

Following Adger and Ramchand (2003), we assume that the copula is a manifestation of the Predicate head (cf. den Dikken 2006):

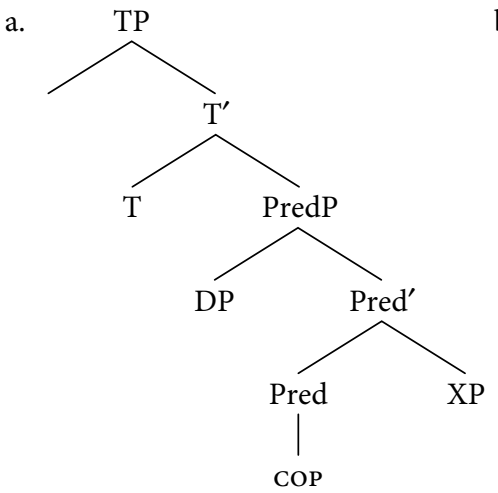

b.

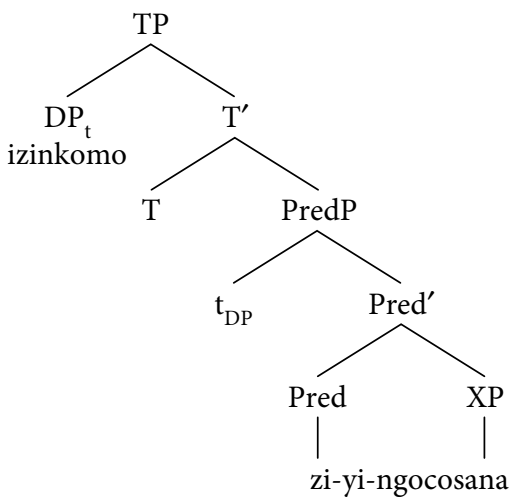

The XP can be a predicate nominal as in the case of $(32 \mathrm{a}-\mathrm{c})$, with the subject DP in SpecPredP. When the subject DP moves to TP, subject agreement is realized (as in $(32 a-c))$. The tree in (37b) illustrates the structure for (32c). This is the same as when we have a verbal predicate, with subject marking reflected in the verb.

In the case of clefts, we suggest, along the lines of Moro (1997) as well as Adger and Ramchand (2003) for similar sentences, that the predicate is a null pronominal element. ${ }^{10,11}$ Following Adger and Ramchand (2003), we suggest

10. Buell (2008) suggests that the class 17 subject agreement reflects agreement with a silent demonstrative similar to the French $c e$.

11. Class 17 agreement in Zulu does not entail that we have locative agreement. Zulu does not really have a locative class in comparison with other Bantu languages. We thank Thilo Schadeberg for pointing this out to us. 
that the structure we find in the cleft sentences involves predicate inversion, with the predicate raising to the subject position (and thus also blocking the subject DP from raising and triggering regular agreement; see Carstens 2005 for the argument that movement is required for agreement in Bantu). Since the copula appears to precede the pivot, this may in fact involve the movement of the Pred' to the SpecTP (similar to the Scottish Gaelic augmented copular sentences discussed in Adger \& Ramchand 2003). Due to the fact that there is no element which can trigger agreement, a default (Class 17) agreement is used (see (40) for the structure).

\subsection{The post-pivot phrase/clause}

With the structure of the copular sentence in place, let us consider now the role and the interpretation of the post-pivot DP phrase/adverbial clause. Adger and Ramchand (2003) discusses a special case of copular sentences, the augmented copular construction, illustrated by the Scottish Gaelic examples in (38a, b):
a. 'S
e Calum.
COP-PRES AUG Calum
'It's Calum.'
b. 'S e Calum Hamlet.
COP-PRES AUg Calum Hamlet
'Calum is Hamlet.'

Adger \& Ramchand proposes that the copula used in augmented copular constructions is a defective copula. It predicates the property denoted by its complement, that is, the pronominal predicate (i.e. the augment), directly of its subject. In the case of (38b), they suggest that Hamlet in (38b) is adjoined (to TP). This right-adjoined DP has a function of explicitly identifying the 'contextually given individual' in the semantics of the pronominal augment with overt linguistic material. For (38b), this yields the interpretation given in (39):

(39) 'The relevant distinguishing property associated with $x$ ' holds of 'Calum', where $x$ is described/replaced by the definite description 'Hamlet'.

(Adger \& Ramchand 2003:353, (102))

Essentially, the semantic value of the pronoun is replaced by a definite description. That is, the adjoined DP provides a definite description for the interpretation of the variable in the semantic representation of the pronominal predicate. The interpretation they provide for the augmented copular construction is similar to the interpretation that Clech-Darbon et al. (1999) provide for French clefts, where the adjoined clause specifies the interpretation of $c e$. 
We propose to extend this analysis to Zulu. Consider again the structure of Zulu clefts. The tree in (40) illustrates the structure of (34a), with predicate inversion, as well as the DP adjoining to CP.

$(40)$

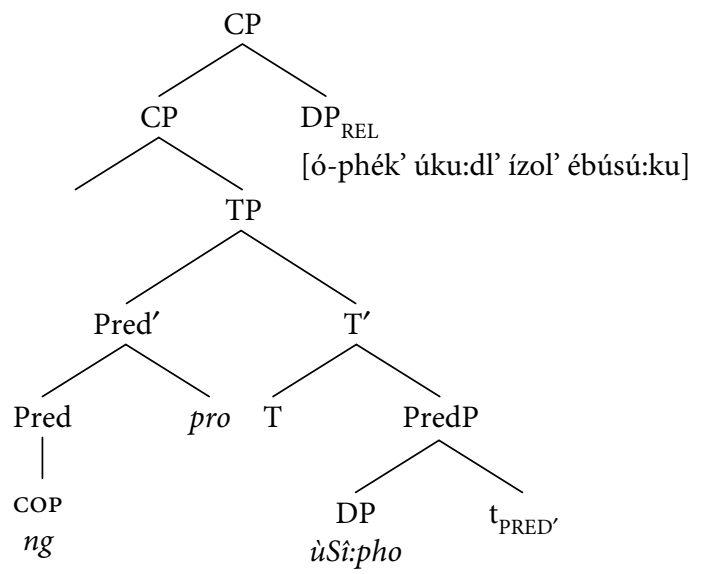

We assume that the DP phrase or adverbial clause is adjoined to CP, yielding the correct prosodic phrasing: this $\mathrm{CP}$ is optimally parsed into a separate Intonation Phrase from the adjoined DP phrase or adverbial clause by the alignment constraints in (13), (14), above. Further, the adjoined DP, for instance, serves to specify the semantic value of the pronominal. Similarly, when the adjoined element is an adverbial clause, it essentially states that the property which holds of a temporal/locative element is specified by the adverbial clause.

\section{Conclusion}

In sum, we have shown that clefts in Zulu involve a copular sentence with an adjoined DP/CP, depending on the nature of the pivot. This analysis accounts for the prosodic properties, as the copular sentence is a CP, parsed into a separate Intonation Phrase from the adjoined DP/CP by the independently-motivated prosodic phrasing algorithm for Zulu. This analysis is the only account which is consistent with the syntactic properties of Zulu clefts. Furthermore, the nature of agreement in Zulu copular sentences supports a pronominal predicate analysis. We expect that clefts which are parsed into two prosodic phrases in other Bantu languages - e.g. Luganda (Hyman \& Katamba, 2010), Chewa, and Tumbuka (Downing, 2012) - will yield to a similar syntactic analysis. 


\section{References}

Adger, David \& Ramchand, Gillian. 2003. Predication and equation. Linguistic Inquiry 34: 325-359.

An, Duk-Ho. 2007. Clauses in noncanonical positions at the syntax-phonology interface. Syntax 10: $38-79$.

Buell, Leston. 2005. Issues in Zulu Verbal Morphosyntax. Ph.D. dissertation, UCLA.

Buell, Leston. 2006. The Zulu conjoint/disjoint verb alternation: Focus or constituency? ZAS Papers in Linguistics 43: 9-30.

Buell, Leston. 2008. Predication types and predicate-internal arguments in Zulu. Ms, University of Leiden.

Buell, Leston. 2009. Evaluating the immediate postverbal position as a focus position in Zulu. Selected proceedings of ACAL 38, 166-172. Somerville MA: Cascadilla Proceedings Project.

Carstens, Vicki. 2005. Agree and EPP in Bantu. Natural Language and Linguistic Theory 23: 219-279.

Cheng, Lisa \& Downing, Laura J. 2007. The prosody and syntax of Zulu relative clauses. In SOAS WPL 15: Bantu in Bloomsbury, Nancy Kula \& Lutz Marten (eds), 51-63. London: SOAS.

Cheng, Lisa \& Downing, Laura J. 2009. Where's the topic in Zulu? In Topics Cross-linguistically, Helen de Hoop \& Geertje van Bergen (eds). Special issue of The Linguistic Review 26: 207-238.

Cheng, Lisa \& Downing, Laura J. 2012. Against FocusP: Evidence from Durban Zulu. In Information Structure: Contrasts and Positions, Ivona Kucerova \& Ad Neeleman (eds). 247-266. Cambridge: CUP.

Chomsky, Noam. 2001. Derivation by phase. In Ken Hale, A Life in Language, Michael Kenstowicz (ed.), 1-52. Cambridge MA: The MIT Press.

Clech-Darbon, Anne, Rebuschi, Georges \& Rialland, Annie. 1999. Are there cleft sentences in French? In The Grammar of Focus [Linguistik Aktuell/Linguistics Today 24], Georges Rebuschi \& Laurice Tuller (eds), 83-118. Amsterdam: John Benjamins.

den Dikken, Marcel. 2006. Relators and Linkers: The Syntax of Predication, Predicate Inversion and Copulas. Cambridge MA: The MIT Press.

Doke, Clement M. 1961. Textbook of Zulu Grammar, 6th edn. London: Longmans.

Downing, Laura J. 2010. Prosodic phrasing in relative clauses: A comparative look at Zulu, Chewa and Tumbuka. In Bantu Languages: Analyses, Description and Theory [East African Languages and Dialects 20], Karsten Legère \& Christina Thornell (eds), 17-29. Köln: Rüdiger Köppe.

Fox, Danny \& Pesetsky, David. 2005. Cyclic linearization of syntactic structure. Theoretical Linguistics 31: 1-45.

Hyman, Larry M. \& Katamba, Francis. 2010. Tone, syntax, and prosodic domains in Luganda. ZAS Papers in Linguistics 63: 69-98.

Hyman, Larry M. \& Polinsky, Maria. 2010. Focus in Aghem. In Information Structure: Theoretical, Typological, and Experimental Perspectives, Malte Zimmermann \& Caroline Féry (eds), 206-233. Oxford: OUP.

Ishihara, Shinichiro. 2007. Major phrase, focus intonation, multiple spell-out (MaP, FI, MSO). The Linguistic Review 24: 137-167.

Kahnemuyipour, Arsalan. 2009. The Syntax of Sentential Stress. Oxford: OUP.

Khumalo, James S.M. 1987. An Autosegmental Account of Zulu Phonology. Ph.D. dissertation, University of the Witwatersrand. 
É. Kiss, Katalin. 1998. Identificational focus versus information focus. Language 74: 245-273. Koch, Karsten. 2008. Intonation and Focus in Nlerkepmxcin (Thompson River Salish). Ph.D. dissertation, University of British Columbia.

Kratzer, Angelika \& Selkirk, Elisabeth. 2007. Phase theory and prosodic spellout: The case of verbs. The Linguistic Review 24: 93-135.

Maxwell, Edith M. 1981. Question strategies and hierarchies of grammatical relations in Kinyarwanda. BLS 7: 166-177.

Moro, Andrea. 1997. The Raising of Predicates: Predicative Noun Phrases and the Theory of Clause Structure [Cambridge Studies in Linguistics]. Cambridge: CUP.

Percus, Orin. 1997. Prying open the cleft. Proceedings of NELS 27: 337-351.

Poulous, George \& Msimang, Christian T. 1998. A Linguistic Analysis of Zulu. Cape Town: Via Afrika.

Selkirk, Elisabeth. 1986. On derived domains in sentence phonology. Phonology Yearbook 3: 371-405.

Selkirk, Elisabeth. 1995. The prosodic structure of function words. UMOP 18: Papers in Optimality Theory: 439-470.

Selkirk, Elisabeth. 2000. The interaction of constraints on prosodic phrasing. In Prosody: Theory and Experiment, Merle Horne (ed.), 231-261. Dordrecht: Kluwer.

Truckenbrodt, Hubert. 1995. Phonological Phrases: Their Relation to Syntax, Focus and Prominence. Ph.D. dissertation, MIT.

Truckenbrodt, Hubert. 1999. On the relation between syntactic phrases and phonological phrases. Linguistic Inquiry 30: 219-255.

Truckenbrodt, Hubert. 2005. A short report on intonation phrase boundaries in German. Linguistische Berichte 203: 273-296.

van der Spuy, Andrew. 1993. Dislocated noun phrases in Nguni. Lingua 90: 335-355.

van der Wal, Jenneke. 2009. Word Order and Information Structure in Makhuwa-Enahara. Ph.D. dissertation, University of Leiden. Utrecht: LOT.

Walusimbi, Livingstone. 1996. Relative Clauses in Luganda. Köln: Rüdiger Köppe.

Wedgwood, Daniel. 2007. Identifying inferences in focus. In On Information Structure, Meaning and Form [Linguistik Aktuell/Linguistics Today 100], Kerstin Schwabe \& Susanne Winkler (eds), 207-228. Amsterdam: John Benjamins.

Zerbian, Sabine. 2006. Expression of Information Structure in the Bantu Language Northern Sotho. ZAS Papers in Linguistics 45. 